\title{
The prevalence of Helminth parasites in the gastro-intestinal tract of wild African sharptooth catfish Clarias gariepinus (Siluriformes: Clariidae) in Gwagwalada, Nigeria
}

\author{
Ahmed S. Dan-kishiya ${ }^{1}$, Angela Oboh ${ }^{1}$ and Usman B. Ibrahim ${ }^{2}$ \\ 1. Department of Biological Sciences, University of Abuja, P.M.B 117, Abuja, Nigeria; adankishiya@yahoo.com \\ 2. Department of Biological Sciences, Ahmadu Bello University, Zaria, Nigeria
}

Received 21-VI-2012 Corrected 23-XI-2012 Accepted 17-I-2013

\begin{abstract}
A study on the gastro-intestinal helminth parasites of wild C. gariepinus was carried out in Gwagwalada Area Council of FCT, Abuja, Nigeria. A total of 110 samples were examined which includes 42 males and $68 \mathrm{fe}$ males. Forty-eight $(43,64 \%)$ fishes were infected with various species of helminth, which includes Wenyonia spp. $(28,18 \%)$, Procamallanus laevionchus (11,82\%) and Euclinostomum heterostomum (3,64\%). The female fish had the highest percentage prevalence $(28,18 \%)$ while the males had $15,46 \%$ prevalence. Most of the parasites were recovered from the intestinal lumen. There was some degree of specificity in their distribution within the host but there was no significant difference $(P>0,05)$ between the standard length, body weight, number of fish infected, prevalence and the intensity of infection.
\end{abstract}

\section{KEY WORDS}

Helminth parasites, wild, C. gariepinus, gastro-intestinal tract, Gwagwalada.

\section{RESUMEN}

Estudio sobre helmintos parásitos gastro-intestinales de C. gariepinus silvestre en Gwagwalada, Consejo del Área de FCT, Abuja. Un total de 110 muestras examinadas incluyeron 42 machos y 68 hembras. Cuarenta y ocho $(43,64 \%)$ peces se encontraban infectados con diversas especies de helmintos como Wenyonia spp. (28,18\%), Procamallanus laevionchus $(11,82 \%)$ y Euclinostomum heterostomum $(3,64 \%)$. Los peces hembra tenían el mayor porcentaje de prevalencia $(28,18 \%)$, mientras que los machos tenían 15,46\%. La mayoría de los parásitos se encontraron en el lumen intestinal. Hubo algún grado de especificidad en la distribución dentro del huésped, pero no hubo diferencia significativa $(P>0,05)$ entre la longitud estándar, el peso corporal, el número de peces infectados, la prevalencia y la intensidad de la infección.

\section{PALABRAS CLAVE}

Helmintos parásitos, silvestre, C. gariepinus, tracto gastrointestinal, Gwagwalada.
Interest in the development of fish farming and culture has increase tremendously in recent times in Nigeria. Some of the factors responsible for the cultivation of fish are consumption, scientific studies, economic benefits and ornamental purposes. The country has a large population of domesticated livestock comprising of cattle, sheep, goats as well as poultry, which constitute the major source of animal protein to the populace. However, in spite of these animals' resources, production has remained grossly inadequate in meeting national protein requirements (Okorie, 1981). But, fish is one of the cheapest sources of animal protein, especially with the rapidly increasing human population and consequent increase in protein demand.
A number of fish parasites have been discovered to be of known zoonotic potential to mammalian host including man therefore, making them of public health importance (Ukoli, 1984). The larval stage of the digenetic trematode parasite, Diplostomum spatheceum (eye fluke) has been shown to penetrate fish body and within 12 hours, $80 \%$ of the parasites are found in the lens of the eye, suggesting the existence of a powerful chemotaxis (Stabbles \& Chapple, 1986). Digenetic trematodes, Clinostomum and Euclinostomum species were recovered from Heterotis niloticus, and Clarias gariepinus in which the adult trematodes are found in digestive tracts, liver, gall bladder and urinary bladder (Oniye \& Annune, 1993). Khali (1971) listed over 50 species of trematodes from 15 families, occurring 
in a variety of fresh water fishes in Africa, of these; only the extra intestinal species are potentially harmful to fish. Adult trematodes infecting the digestive tract of fishes are considered harmless even when their numbers are high. Paperna (1996) showed that extra intestinal trematode infections are potentially pathogenic.

Many researches on fish parasites has been conducted in Nigeria (Auta, Oniye, \& Adakole, 1999; Yakubu, Omoregie, Wade, \& Faringo, 2002; Oniye, Adebote, \& Ayanda, 2004; Emere \& Egbe, 2006) but in spite of the high commercial value of $C$. gariepinus in Gwagwalada, the only documented work was that of Dankishiya and Zakari (2007). It is base on the above that the study was undertaken to review the parasite fauna of this importance species.

\section{METHODOLOGY}

\section{Study area}

The study was conducted in Gwagwalada the headquarters of Gwagwalada area council, which is one of the six area councils in Abuja the federal capital territory (FCT) of Nigeria. Abuja is located in the centre of Nigeria with a land area of $8000 \mathrm{~km}^{2}$. It lies between the Latitude of $8^{\circ} 25^{\prime \prime}$ and $9^{\circ} 25^{\prime \prime} \mathrm{N}$ and Longitude $6^{\circ} 45^{\prime \prime}$ and $7^{\circ} 45^{\prime \prime} \mathrm{E}$. It is bounded to the North by Kaduna and Niger States, to the South by Kogi State, East by Nasarawa State and West by Niger State (Fig.1). From its Central location its vegetation combines the savannah grassland type of the North and middle belt with the tropical rain forest type of the South of Nigeria.

Gwagwalada with an area of $1043 \mathrm{~km}^{2}$ is one of the largest satellite towns in the FCT with a population of 157770 as at 2006 population census. Due to the large influx of people on a daily basis and the presence of River Usuma which is an important tributary of River Gurara in the study area besides numerous tributaries with a lot of fishing activities make Gwagwalada town an important commercial fish market.

\section{Fish Sampling}

One hundred and ten live specimens of C. gariepinus of different sizes were bought from local fishermen landings along secretariat road in Gwagwalada, Nigeria. The fish were identified using Olaosebikan and Raji (2004) and Holden and Reed (1972). The total lengths, standard lengths and body weights were measured using standard methods described by Olatunde (1977). The sexes of the

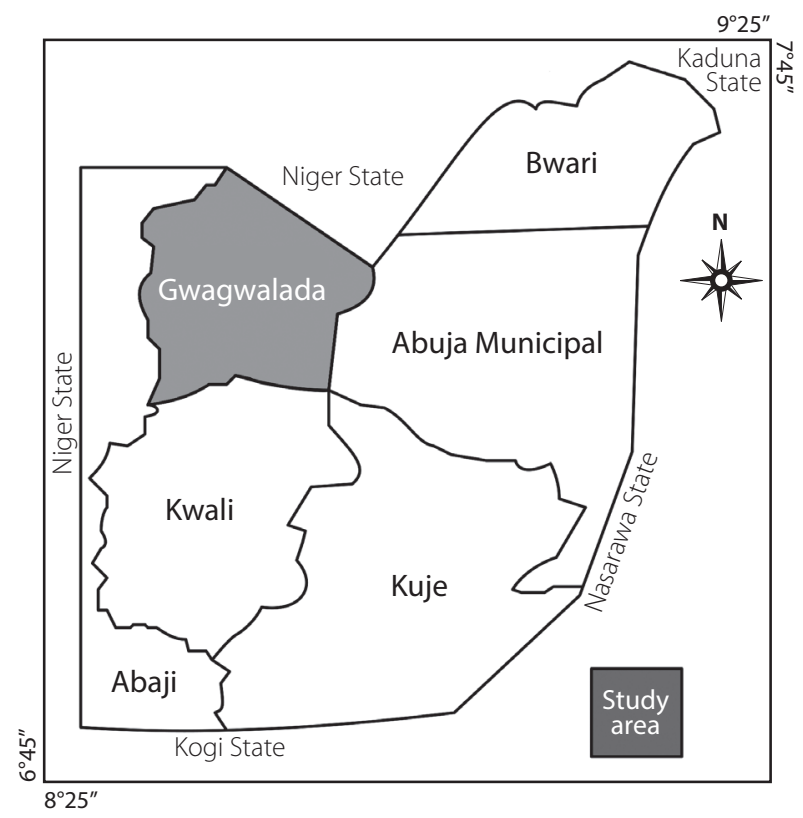

Fig. 1. Abuja, Federal Capital Territory of Nigeria Showing the Study Area.

fishes were determined by visual examination of the urinogenital system.

For the parasites survey, the fishes were dissected through the abdomen by making a longitudinal slit on the ventral surface from the anus to a point level with the pectoral fins using a surgical blade. The alimentary canals of the dissected fishes were grouped into Oesophagus, Stomach and Intestine, and placed into three separate Petri dishes containing 0,85\% normal saline. Each portion was washed in the normal saline and then examined for parasites under a dissecting microscope. Parasites found were transferred into another Petri dish containing normal saline and counted. The recovered parasites were placed in normal saline overnight in a refrigerator. This enables the parasites to stretch and relax. The parasites were preserved in specimen bottles containing $5 \%$ formalin and labeled with the autopsy number, name of host, date of collection and the sites from which the parasites were recovered. For the fixing the parasite was mounted on a slide and covered with a cover slip then placed on ice block for 3-5 minutes, to arrest the cells then it was removed and dried, finally it was fixed using Canada balsam. 
Parasites were identified using texts by Paperna (1996), Kabata (1985) and Roberts (1978).

\section{RESULTS}

A total of 110 wild C. gariepinus were examined out of which $42(38,18 \%)$ were males and $68(61,82 \%)$ were females. The total number of parasites, percentage infection, prevalence and sites of infection is showed in Table 1. A total of 302 helminthes parasites belonging to three classes, the Cestoda, Nematoda and Trematoda were recovered from the oesophagus, stomach and intestine respectively. The highest number of parasites was recovered from the intestine (224 parasites). This was followed by the stomach with 67 parasites while; the oesophagus was the least (11 parasites). Thirty-one fishes were infected with cestodes of the genus Wenyonia spp with a prevalence rate of $28,18 \%, 13(11,82 \%)$ fishes were infected by the Nematode (P. laevionchus) while the trematode (E. heterestomum) infected $4(3,64 \%)$ fishes.
The rate of infection of wild C. gariepinus with parasites in relation to their standard length is presented in Table 2. Fishes with standard length between $26-30 \mathrm{~cm}$ had the highest parasites load of $219(72,52 \%)$ with a prevalence of $32,73 \%$ and mean intensity of 6,08 . This was followed by fishes of length range of between $31-35 \mathrm{~cm}$ having a parasites load of $72(23,84 \%)$ with a prevalence rate of $8,18 \%$ as well as mean intensity of 8,00 . The least was fishes within the range of $21-25 \mathrm{~cm}$ with a parasites load of 11 representing $3,64 \%$ of the total parasites recovered with a prevalence rate of $2,73 \%$. While those within the range of $36-40 \mathrm{~cm}$ were not infected.

The rate of infection in relation to body weight of fish with helminthes parasites is shown in Table 3. The fish with body weight range between 101-151g considered as juveniles has no parasitic infection. Sub juvenile with body weight range between $156-210 \mathrm{~g}$ was infected with a total of $42(13,91 \%)$ parasites and an intensity of 8,40 . The highest infection of $149(49,34 \%)$ parasites was recorded in the adult with body weight range of $266-320 \mathrm{~g}$ with an intensity of 7,10 . Fishes with body weight of $321-375 \mathrm{~g}$ were

TABLE 1

Prevalence of intestinal Helminth parasite in wild C. gariepinus in Gwagwalada, Nigeria

\begin{tabular}{lcccccc}
\hline \multirow{2}{*}{$\begin{array}{c}\text { Parasites } \\
\text { Taxonomy/Species }\end{array}$} & $\begin{array}{c}\text { Number of } \\
\text { fish infected }\end{array}$ & \% Prevalence & \multicolumn{3}{c}{ Location of parasites } & \begin{tabular}{c} 
Total number of \\
\cline { 4 - 5 } parasites recovered (\%)
\end{tabular} \\
\hline $\begin{array}{l}\text { Cestoda } \\
\quad \text { W. acuminate }\end{array}$ & 31 & 28,18 & 11 & 42 & 162 & $215(71,19)$ \\
$\begin{array}{c}\text { Nematoda } \\
\quad \text { P. lavionchus }\end{array}$ & 13 & 11,82 & 0 & 25 & 53 & $78(25,83)$ \\
$\begin{array}{c}\text { Trematoda } \\
\text { E. heterostomum }\end{array}$ & 4 & 3,64 & 0 & 0 & 9 & $9(2,98)$ \\
$\begin{array}{c}\text { Total } \\
\text { Intestine }\end{array}$ & 48 & 43,64 & 11 & 67 & 224 & 302
\end{tabular}

TABLE 2

Rate of Infection of wild C. gariepinus with Helminthes parasites in relation to standard length

\begin{tabular}{|c|c|c|c|c|c|}
\hline $\begin{array}{c}\text { Standard } \\
\text { length }(\mathbf{c m})\end{array}$ & $\begin{array}{c}\text { Number of fish } \\
\text { examined }\end{array}$ & $\begin{array}{c}\text { Number of fish } \\
\text { infected }\end{array}$ & $\begin{array}{c}\text { Total number of } \\
\text { parasite recovered }\end{array}$ & \% Prevalence & $\begin{array}{c}\text { Average intensity } \\
\text { of infection/fish }\end{array}$ \\
\hline $21-25$ & $23(20,91)$ & $3(13,04)$ & $11(3,64)$ & 2,73 & 3,67 \\
\hline $26-30$ & $49(44,45)$ & $36(73,47)$ & $219(72,52)$ & 32,73 & 6,08 \\
\hline $31-35$ & $30(27,27)$ & $9(30,00)$ & $72(23,84)$ & 8,18 & 8,00 \\
\hline $36-40$ & $8(7,27)$ & 0 & 0 & 0 & 0 \\
\hline Total & 110 & $48(43,64)$ & 302 & 43,64 & 17,75 \\
\hline
\end{tabular}

*Figures in parenthesis represent percentages 
TABLE 3

Helminthes infection in relation to body weight in wild C. gariepinus from Gwagwalada

\begin{tabular}{ccccc}
\hline Body weight (g) & $\begin{array}{c}\text { Number of fish } \\
\text { examined }\end{array}$ & $\begin{array}{c}\text { Number of fish } \\
\text { infected }\end{array}$ & $\begin{array}{c}\text { Total number of } \\
\text { parasite recovered }\end{array}$ & Intensity \\
\hline $101-155$ & $8(7,27)$ & 0 & 0 & 0 \\
$156-210$ & $41(37,27)$ & $5(12,20)$ & $42(13,91)$ & 8,40 \\
$211-265$ & $2(26,36)$ & $14(48,28)$ & $57(18,87)$ & 4,07 \\
$266-320$ & $23(20,91)$ & $21(91,30)$ & $149(49,34)$ & 7,10 \\
$321-375$ & $6(5,45)$ & $5(83,33)$ & $45(14,90)$ & 9,00 \\
$376-422$ & $3(2,73)$ & $3(100,00)$ & $9(2,98)$ & 3,00 \\
Total & 110 & $48(43,64)$ & 302 & 31,57
\end{tabular}

*Figures in parenthesis represent percentages.

TABLE 4

Sex specific rate of intestinal Helminthes infection in wild C. gariepinus from Gwagwalada

\begin{tabular}{cccccc}
\hline Sex & $\begin{array}{c}\text { Number of fish } \\
\text { examined }\end{array}$ & $\begin{array}{c}\text { Number of fish } \\
\text { infected }\end{array}$ & $\begin{array}{c}\text { Total number of } \\
\text { parasite recovered }\end{array}$ & \% Prevalence & Intensity \\
\hline Male & $42(38,18)$ & $17(40,48)$ & 85 & 15,46 & 5,00 \\
Female & $68(61,82)$ & $31(45,59)$ & 217 & 28,18 & 7,00 \\
Total & $110(100,00)$ & $48(43,64)$ & 302 & 43,64 & 12,00
\end{tabular}

${ }^{*}$ Figures in parenthesis represent percentages.

infected with $45(14,90 \%)$ parasites with intensity of 9,00. While, fishes with body weight range of $376-422 \mathrm{~g}$ had the least infection of $9(2,98 \%)$ parasites and intensity of 3,00 .

The relationship between sex and rate of infection is as showed in Table 4. Out of 110 fishes examined, 42(38,18\%) and $68(61,82 \%)$ were males and females respectively. Seventeen males were infected representing $40,48 \%$ of the total males sampled with a prevalence rate of $15,46 \%$ and mean intensity of 5,00. While, $31(45,59 \%)$ females fish were infected with a prevalence of $28,18 \%$ with an intensity of 7,00 throughout the study period.

\section{DISCUSSION}

The study on gastrointestinal helminthes parasites of wild C. gariepinus in Gwagwalada, Nigeria showed that the fishes were infected with 3 species of parasites involving the cestodes (Wenyonia spp), Nematode (Procamallanus laevionchus) and Trematode (Euclinostomum heterostomum). This is in conformity with other researchers. Dankishiya and Zakari (2007) identified the Cestodes, Nematode and Trematode, in wild C. gariepinus in Gwagwalada. Onwuliri and Mgbemena (1987), Oniye and Annune (1993) found the trematode (Euclinostomum spp.) in the intestine and digestive tracts of Clarias gariepinus. Yakubu et al. (2002), found C. gariepinus infected by Procamallanus laevionchus in River Uke, Plateau State.

The prevalence rate of $43,64 \%$ in the present study is in conformity with previous work in Gwagwalada (Dankishiya \& Zakari, 2007). While other researches in Nigeria such as Onwuliri and Mgbemena (1987) reported a prevalence of $63,00 \%$ in wild population of C. gariepinus and $59,8 \%$ in cultured C. gariepinus in Jos, Plateau State. Anosike, Omoregie, Ofojekwu, and Nweke, (1992) reported a prevalence of $34,7 \%$ in wild population of C. gariepinus in Plateau State, while Oniye et al. (2004), reported a prevalence of $19,17 \%$ in Zaria, Kaduna State. 
An increase in size is a reflection of increase in length and weight, which is hereby considered as a measured of age. Therefore, the juvenile fish had no parasite while the sub-adults and adults had higher prevalence this implies that infestation increased with age of fish. This was attributed to change in diet from weeds, seeds, phyto and zooplanktons as juveniles to insect larvae, snail's, crustaceans, worms and fishes as adult is attained (Reed, Burchard, \& Hopson, 1967; Anosike et al., 1992). Also the lower prevalence rate of adult fish to parasitaemia might be due to the fact that adult fish may have acquired immunity as a result of an earlier exposure to parasites and other factors. Onwuliri and Mgbemena (1987) showed that the environment is known to play an important role in parasite prevalence.

\section{ACKNOWLEDGEMENTS}

Laboratory Technologist, Department of Biological Sciences, University of Abuja for their assistance.

\section{REFERENCES}

Anosike, J.C., Omoregie, E., Ofojekwu, P.C. \& Nweke, I.E. (1992). A survey of Helminths parasites of Clarias gariepinus in Plateau State. Nigerian Journal of Aquatic Sciences, 7, 39-43.

Auta, J., Oniye, S.J. \& Adakole, J.A. (1999). The helminthes Parasites of the Gastrointestinal tract of Synodontis Species in Zaria, Nigeria. Zuma: Journal of Pure and Applied Sciences, 2(2), 47-53.

Dankishiya, A.S. \& Zakari, M. (2007). Study on the Gastrointestinal Helminth Parasites of Clarias gariepinus (Teugels) in Gwagwalada, FCT, Nigeria. Biological and Environmental Science Journal for the Tropics, 4(2), 79-81.

Emere, M.C. \& Egbe, N.E.L. (2006). Protozoan Parasites of Synodontis Clarias (A Freshwater Fish) in River Kaduna. Biological and Environmental Sciences Journal for the Tropics, $3(3), 58-64$.

Holden, M. \& Reed, W. (1972). West Africa Fresh Water Fish. Publishers, Longman Group Limited: London, England.
Kabata, Z. (1985). Parasites and diseases of fish cultured in the tropics. Taylor and Francis: London, England.

Khalil, L.F. (1971). Checklist of the helminthes parasites of African freshwater fishes. Commonwealth Agriculture Bureau: London, England.

Okorie, J.U. (1981). A guide to Livestock production in Nigeria. Macmillan Education Limited: United Kingdom.

Olaosebikan, B.D. \& Raji, A. (2004). Field guide to Nigerian freshwater fishes. Federal College of Freshwater fisheries technology. Unilorin University Press: New Bussa, Niger State.

Olatunde, A.A. (1977). The distribution, abundance and trends in the establishment of the family Schilbeidae (Osteichthyes: Siluriformes) in Lake Kainji, Nigeria. Hydrobiologia. $56,69-80$.

Oniye, S.J. \& Annune, P.A. (1993). Common fish diseases: Prevention and control. Proceedings of National workshop on Fisheries Extension Delivery, 1, 26-29.

Oniye, S.J., Adebote, D.A. \& Ayanda, A.I. (2004). Helminths parasites of Clarias gariepinus (Teugels) in Zaria, Nigeria. Journal of Aquatic Sciences, 19(2), 71-75.

Onwuliri, C.O.E. \& Mgbemena, M.O. (1987). The parasitic fauna of some fresh water fish from Jos, Plateau, Nigeria. Journal of Applied Fisheries and Hydrobiology, 2, 33-37.

Paperna, I. (1996). Parasites, Infections and Diseases of Fishes in Africa: An update. FAO/CIFA Technical paper, 31, FAO: Rome, Italy.

Reed, W., Burchard, J. \& Hopson, A.J. (1967). Fish and fisheries of Northern Nigeria, Ministry of Agriculture, Kaduna Government Printer: Northern Nigeria.

Roberts, R.J. (1978). Fish Pathology. Bailliere Tindal: London, England.

Stabbles, J.N. \& Chappel, L.H. (1986). Diplostomum spatheccum of physical factors of infection of Rainbow trout (Salmon gadneirri) by cercarie, from North East Scotland. Parasitology, 92, 699-710.

Ukoli, F.M.A. (1984). Introduction to parasitology in Tropical Africa. John Wiley \& Sons Limited: United Kingdom.

Yakubu, D.P., Omoregie, E., Wade, J.W. \& Faringo, D.U. (2002). A comparative study helminthes of gut of T. zilli and C. gariepinus from river Uke, Plateau State. Nigerian Journal of Aquatic Science, 92,137-139. 
